\title{
JUSTIÇA RESTAURATIVA: UM CAMINHO POSSÍVEL NA SUPERAÇÃO DA RACIONALIDADE PENAL MODERNA?
}

\section{RESTORATIVE JUSTICE: A POSSIBLE WAY TO OVERCOME MODERN CRIMINAL RATIONALITY?}

\author{
Daniela Carvalho Almeida da Costa \\ Universidade Federal de Sergipe - UFS - (São Cristóvão, SE, Brasil) \\ Elisio Augusto de Souza Machado Júnior \\ Universidade Federal de Sergipe - UFS - (São Cristóvão, SE, Brasil)
}

Recebimento: 31 jul. 2017

Aceitação: 6 out. 2017

\begin{abstract}
Como citar este artigo / How to cite this article (informe a data atual de acesso / inform the current date of access):
COSTA, Daniela Carvalho Almeida da; MACHADO JÚNIOR, Elisio Augusto de Souza. Justiça Restaurativa: um caminho possível na superação da racionalidade penal moderna? Revista da Faculdade de Direito UFPR, Curitiba, PR, Brasil, v. 63, n. 1, p. 65-91, abr. 2018. ISSN 2236-7284. Disponível em: <http://revistas.ufpr.br/direito/article/view/54226>. $\quad$ Acesso $\quad$ em: $30 \quad$ abr. $2018 . \quad$ DOI:
\end{abstract} http://dx.doi.org/10.5380/rfdufpr.v63i1.54226.

\section{RESUMO}

O presente artigo parte da hipótese de a Justiça Restaurativa se apresentar como possível caminho para se lidar com as questões formuladas pelo abolicionismo penal. Desde sua institucionalização, a pena serviu como instrumento de controle e manutenção do poder punitivo que, substituindo as partes envolvidas, atribuiu ao modelo verticalizado de justiça a difícil responsabilidade de solucionar o conflito. O longo processo de estruturação do sistema punitivo culminou na adoção do cárcere como novo paradigma, com o consequente desenvolvimento de teorias que buscaram legitimar a pena. Contudo, essa tentativa de justificação dogmática foi incapaz de mascarar as falhas da racionalidade penal moderna, havendo, pois, a necessidade de superação do antigo modelo. Logo, a pesquisa tem como objetivo central analisar, a partir do marco da criminologia crítica, por meio de revisão de literatura, o colapso das teorias da pena e identificar em que medida a Justiça Restaurativa implica ruptura com a racionalidade penal moderna e propõe um novo paradigma para compreensão e solução do conflito.

\section{PALAVRAS-CHAVE}

Sistema punitivo. Racionalidade penal moderna. Criminologia crítica. Abolicionismo. Justiça Restaurativa.

\begin{abstract}
The present article starts from the hypothesis that Restorative Justice is presented as a possible way to deal with the questions formulated by the penal abolitionism. Since its institutionalization, penalty has served as an instrument of control and maintenance of the punitive power that, replacing the parties involved, attributed to the vertical model of justice the difficult responsibility of solving the conflict. The long process of structuring the punitive system culminated in the adoption of jail as a new paradigm, with the consequent development of theories that have tried to legitimate the penalty.
\end{abstract}


However, this attempt at dogmatic justification has been unable to mask the flaws of modern penal rationality, and therefore there is a need to overcome the old model. The main objective of this research is to analyze, from the perspective of critical criminology, through a literature review, the collapse of theories of punishment and to identify to which extent Restorative Justice implies rupture with the modern penal rationality and proposes a new paradigm for the understanding of conflicts and their resolution.

\section{KEYWORDS}

Punitive system. Modern criminal rationality. Critical criminology. Abolitionism. Restorative Justice.

\section{INTRODUÇÃO}

A pena institucionalizada como consequência natural da prática de um crime é um antigo instituto com o qual a sociedade se acostumou a conviver, aceitando-a acriticamente. Essa tácita anuência esconde uma antiga racionalidade, construída pelo poder punitivo estatal para acobertar um programa de controle e dominação das massas. Por diversas vias, o Estado se esforçou na tentativa de legitimar o uso da pena, particularmente da pena de prisão, mediante o discurso não só de controle e retribuição, mas também de melhoria íntima do condenado, que se tornaria apto ao convívio social; ou seja, um jogo em que todos sairiam ganhando.

A racionalidade penal moderna enxerga o crime como violação da lei, numa perspectiva universalizante de justiça, cuja vítima central sempre será o Estado, alijando as partes do conflito que outrora lhes pertencia. A universalidade do direito, uma das premissas do Estado moderno, captura, ademais do monismo jurídico, o conflito, a partir da moldura da legalidade, conferindo-lhe uma roupagem formal, cuja sanção, previamente cominada em lei, será aplicada de forma pretensamente igualitária e proporcional a todo aquele que, violando a lei penal, preencher os requisitos dogmáticos para a configuração do delito.

Essa racionalidade, que nos captura pelo paradigma universalizante do castigo e da punição, vem sendo ao longo do tempo desvelada. As construções teóricas que se desenvolveram em torno da pena buscaram artificialmente encontrar uma finalidade, algo que pudesse de algum modo explicar como a aflição daqueles que praticaram uma conduta penalmente relevante seria capaz de produzir resultados socialmente positivos. Ocorre que também a dogmática possui recursos limitados às suas elaborações, e todos eles foram esgotados na hercúlea tarefa de conferir roupagens que mascarassem um instituto essencialmente contrário aos seus propósitos.

Embora conceitos e imagens estereotipadas dos delinquentes ainda permaneçam socialmente arraigados - resultado de um longo processo que, paralelamente à pena, transformou a figura do criminoso na encarnação do mal, transmutando o problema da ineficácia das políticas públicas para 
o fato de aqueles existirem -, o cárcere passou a ser alvo de constantes críticas. Conquanto apenas tangenciem o cerne do problema, questões como a superlotação de presídios e a ausência de condições minimamente dignas têm chamado atenção para o fato de que o sistema está prestes a ruir e que aqueles que lá se encontram, prestes a retornar às ruas, nada trarão consigo além do ódio.

Por estas razões, de há muito conhecidas e debatidas academicamente, há um sentimento de urgência em se encontrar novos modelos que consigam satisfatoriamente responder aos conflitos sociais de maior gravidade. Novos caminhos, para além do cárcere, passam a ser cada vez mais discutidos e considerados como recurso possível e socialmente adequado à resolução de conflitos. É preciso, pois, ter como ponto de partida a abordagem crítica ao sistema penal e à pena de prisão para propor e experimentar vias alternativas.

Mesmo as modalidades de pena que não atingem o direito fundamental à liberdade não rompem com a racionalidade moderna, na medida em que carregam consigo antigos dogmas penais que eliminam qualquer possibilidade real de solução do conflito. Não há espaço para as partes diretamente envolvidas no conflito expressarem suas impressões e sentimentos acerca do mesmo. Não há espaço para diálogo entre os opostos. O Estado aplicará a lei ao condenado, substituindo a vítima, alijando-a completamente do conflito, ignorando sua dor e necessidades. E constrói-se uma crença que a aplicação vertical da lei será suficiente para gerar justiça às partes. É uma ideia vertical e hierarquizada de justiça e, portanto, artificial, uma vez que diz muito pouco aos diretamente envolvidos no conflito, seja ao condenado, seja à vítima, seja à comunidade.

Um contraponto a esse modelo perpassa pela devolução do conflito às partes e à comunidade, sem que haja exatamente um alheamento do Estado, pois não se deseja uma ruptura com o Estado de Direito e com a legalidade. Entretanto, é possível pensar um modelo dialogal, pautado na horizontalidade das relações mediante o empoderamento dos atores envolvidos: a Justiça Restaurativa, objeto central deste artigo. A Justiça Restaurativa, alicerçada nas constatações da criminologia crítica, pressupõe um novo paradigma para compreender e lidar com o conflito, assentado em um senso dialógico e comunitário de humanidade, que nos leve a uma paulatina desconstrução e superação da racionalidade penal moderna.

A pesquisa partiu da crítica ao sistema carcerário, desconstruindo o arcabouço teórico que busca legitimar a sanção como resposta adequada à prática de uma conduta penalmente relevante. Para tanto, delimitou-se a análise no instituto da pena, que foi revisitada desde os seus primórdios, com o escopo de se demonstrar como a racionalidade penal se desenvolveu ao longo do tempo. Em um segundo momento, o estudo se concentrou na criminologia crítica, especialmente na vertente abolicionista, fonte em que o modelo de Justiça Restaurativa vai colher seus principais fundamentos. 
Como método, optou-se pela revisão bibliográfica dos principais autores nacionais e internacionais destacadamente no campo da criminologia crítica - que estabeleceram as críticas ao sistema penal e desenvolveram as bases do modelo restaurativo ainda inconcluso.

\section{A RACIONALIDADE PENAL MODERNA}

Os olhos semicerrados excluem do campo de visão a zona periférica, relegando ao total desconhecimento o vasto mundo que circunda seu horizonte estreito e delimitado; embora parcialmente abertos, estão também parcialmente fechados. O mundo visto por esse feixe de pálpebras entreabertas é tanto antítese quanto proteu; aquilo que pouco se vê, embora não seja por completo uma ficção, é algo diverso da realidade, apenas parcialmente alcançada pela má utilização do sentido. Conquanto parcialmente inspirada por algo real, aquele arremedo, mundo de fato não o é.

A visão, acostumada à ilusão, passa a ter nela uma zona de conforto. Nada, que não essa própria realidade fictícia, é segura aos olhos que se negam a ver. O tempo e o costume lhe impõem tacitamente a crença de que o desconhecido é misteriosamente perigoso e que a imaginação é um exercício de realidade. Nesse estado de coisas, a luz torna-se uma espécie de inimigo figadal, capaz de levar à cegueira aqueles que nunca a tenham encarado plenamente.

A metáfora dos olhos semicerrados representa a forma por meio da qual o poder punitivo construiu um véu para encobrir a falência do sistema em que se assenta a racionalidade da pena. $\mathrm{O}$ sistema carcerário não foi capaz de atender às hercúleas tarefas que lhe foram atribuídas desde que a pena de prisão se tornou o paradigma punitivo, ruindo em virtude do sobrepeso que é sustentar uma ilusão por tempo em demasia. A sociedade tornou-se refém de um mito por ela mesma edificado: de que os grilhões são instrumentos capazes de garantir a ordem e a segurança; de que a violência, desde que exercida pelo monopólio do Estado, pode, enfim, trazer a paz.

Todavia, essa crença na alegoria do cárcere nem sempre esteve presente, de modo que a sanção, tal como hoje é concebida, não pode ser considerada como algo inerente à vida em comunidade ou como resposta congênita ao conflito. Pelo contrário, decorre ela de uma lógica utilitarista - ideia de meio para realização de um fim -, cujos discursos de justificação, durante muito tempo, se mantiveram limitados a análise restritiva da autopoiese do direito penal (FARIA COSTA, 2005, p. 870-871).

Scheerer (2010, p. 968-969), ao tratar sobre o mito da universalidade da pena, ressalta que estudos antropológicos demonstraram que o controle nas sociedades livres de domínio não era exercido a partir da repressão, mas dirigido à reinserção social do sujeito. Para essa antropologia 
social que se desenvolveu a partir de experiências etnográficas e que servem a Scheerer como referencial teórico, “as produções simbólicas são simultaneamente produções sociais que sempre decorrem de práticas sociais” (LAPLANTINE, 2003, p. 91).

A pena, como resposta institucionalizada, não seria, então, uma constante, mas o produto de uma escolha cultural, num contraponto à visão de Franz von Liszt (2006, p. 5), para quem “o ponto de partida da história da pena coincide com o ponto de partida da história da humanidade”. Nesse contexto, passa a importar qual terá sido a origem dessa racionalidade penal moderna ${ }^{1}$ e as circunstâncias preponderantes para formatação da sua lógica.

Embora não se possa precisar o marco temporal no qual se originou o instituto da pena - que apareceu e sumiu várias vezes ao longo da história -, surge ele com a verticalização das relações, quando se passa a exigir a força do poder punitivo para manutenção de uma estrutura hierarquizada. A instalação da racionalidade penal moderna, ancorada na atribuição hierarquizada e institucionalizada da punição, remonta-nos aos séculos XII e XIII, com a apropriação da vítima pelo detentor do poder político, que também passou a ser o poder punitivo, enquanto que sua adoção generalizada como modelo só se concluiu no século XIX (ZAFFARONI, 2012; ZEHR, 2008, p. 103).

Houve uma consequente transformação do conflito e dos meios empregados para resolvê-lo. Os comportamentos reputados como graves passaram a ser identificados não mais segundo os danos provocados às partes envolvidas, mas selecionados segundo a distanciada compreensão dos detentores do poder. Ao desvalor do comportamento deveria se responder com a pena criminal, enquanto expressão de justiça monopolizada.

O ato de penar institucionalizou-se; a usurpação da figura do ofendido - antes ator principal no processo de responsabilização pelo fato - estabeleceu novos paradigmas que se perpetuaram. Visto que a relação bilateral ofensor/ofendido foi relegada ao plano secundário, o processo para atribuição de culpa passou a considerar não mais os interesses dos atores que intervieram no fato, mas a obediência a critérios de conveniência estatal.

As antigas formas privadas de resolução que se aplicavam a núcleos comunitários mais simples foram, na medida em que essas antigas células se tornaram organismos sociais maiores, substituídas por uma lógica de interação mais complexa. É possível identificar, com efeito, uma correlação entre essa hierarquização do poder e o surgimento de uma sanção verticalizante, que passa

\footnotetext{
${ }^{1}$ A racionalidade penal moderna, no sentido aqui empregado, diz respeito ao sistema de pensamento apropriado pelo direito penal para legitimar o poder punitivo e seus instrumentos de controle, destacadamente o cárcere. Com efeito, a racionalidade penal é o resultado das diversas teorias da pena; o programa que se descortina a partir da análise fenomenológica do instituto da pena.
} 
a servir como instrumento de dominação coercitiva neste novo modelo estrutural de sociedade (ZAFFARONI, 2012, p. 42).

Essa compreensão é equivalente à superação do “estado primitivo” em Rousseau: passa-se a compreender a pena como instituto elementar à manutenção do contrato social e como um ato próprio de soberania. De modo tal, desde a sua concepção institucional como monopólio no uso da força, “a pena só se explica - e só pode ser explicada - em sua função simbólica de manifestação de poder e em sua finalidade não explicitada de manutenção e reprodução deste poder” (KARAM, 1997, p. 67).

Não há nisso, entretanto, propriamente uma evolução na busca por um ideal de justiça e paz. Afirmar que a institucionalização da pena tem como saldo positivo imediato a eliminação da vingança privada que originalmente constituía um direito-dever subjetivo da vítima é uma conclusão reducionista. Ela não só desconsidera diversos fatores secundários, a exemplo da crueldade das primeiras espécies de pena, mas também obscurece o fato de que essa substituição buscou atender a um projeto de poder, como instrumento para estruturar um modelo piramidal de dominação que simbolicamente representasse a superação da barbárie a partir do alijamento das partes do conflito.

As primitivas formas de regulação social - espécies de mecanismos naturais de resolução dos conflitos - existentes muito antes dos governos ou mesmo da existência dos chamados Estados não se restringiam ao uso desmedido da força pelo ofendido ou por quem o representasse. Inobstante a regra do talião fosse de uso corriqueiro, não era o derramamento de sangue a única via para atribuição de responsabilidade ao ofensor ${ }^{2}$.

Embora essa “dissociação entre juiz e parte lesada” (FERRAJOLI, 2014, p. 310) de fato represente um segundo passo sob o ponto de vista histórico, apenas institucionalmente pode ser considerada um avanço civilizatório, na medida em que formalizou e reforçou sistemas de controle social informalmente exercido. Contudo, o surgimento da pena não foi simultâneo à criação dos limites à sua imposição; havia inicialmente uma confusão entre ilícitos civis, administrativos e penais, cuja distinção, obediente a critérios de discricionariedade estatal, limitava-se ao rigor desproporcional da sanção imposta (GARCIA ALBERTO, 2001).

Com efeito, ao contrário do que afirma Ferrajoli (2014, p. 309), não é o direito penal que nasceu como uma negação àquilo que o autor italiano denomina de vingança privada; isso demarca o

\footnotetext{
${ }^{2}$ Havia sociedades nas quais predominavam as relações horizontais e comunitárias, a exemplo dos germânicos, que apelavam para soluções reparadoras de seus conflitos (ZAFFARONI, 2012, p. 42), e sociedades primitivas que obedeciam a um sistema de obrigações vinculantes, sem recorrer à imposição da pena, mas tão somente da responsabilização pelo descumprimento de uma ordem considerada por todos como justa (SCHEERER, 2010, p. 968).
} 
surgimento do instituto da pena enquanto monopólio do Estado. O direito penal, ao contrário, é o resultado histórico da conformação de teorias construídas para estruturar o exercício do poder de punir, ou seja, para delimitar em que circunstâncias a pena pode e deve ser imposta.

A separação entre o poder de polícia - parte do direito administrativo - e o direito penal, impulsionada pelas reformas francesas, teve como objetivo justamente delimitar essa ampla discricionariedade do poder sancionador dos Estados, levando para o direito penal as infrações que cominassem graves sanções. Somente a partir dessa delimitação de esferas e atribuições é que surge, como conquista libertária, um sistema de garantias uniformemente aplicado para refrear excessos punitivos (NIETO, 2012, p. 45).

Assim, a pena precede a existência do próprio direito penal, apontando para uma inversão ontológica ao arquétipo da sanção como uma consequência natural do fato típico, ilícito e culpável. Mediante essa lógica, a coercitividade que instrumentaliza o direito penal não só justifica seu posto de última razão, mas também serve de premissa a todos os seus postulados, alocando na pena o centro gravitacional de todo o sistema punitivo. Conforme destacado por Stratenwerth (2010, p. 452-453),

eso es lo que quiso significar cuando Radbruch dijo, respecto del esquema del delito de Beling de tres eslabones, que los elementos del delicto se "deducirían, a partir de entonces, todos del fin de la pena”, o cuando Schimidhäuser quiso que la sistemática de los elementos del hecho punible desarrollada por él fuera entendida como "teleológica", en el sentido de que ella estaba orientada conscientemente a la consecuencia jurídica de la pena.

Dessarte, o direito penal foi edificado na tentativa de impor limites ao exercício institucionalizado e hierarquizado da violência programada, estando aquele necessariamente vinculado à questão fundamental de quando um comportamento humano pode ser adjetivado como criminoso, cuja resposta exige uma solução técnica e internamente perquirida. A pena, por sua vez, trata de questões diversas e que estruturalmente precedem à seleção de bens jurídicos que devem ser teoricamente tutelados quando da delimitação dos comportamentos de relevância penal.

Antes de ser formulada a indagação de quando e como se deve punir - que delimita o campo de justificação teórica quando restam satisfeitos requisitos específicos de imputação que servem de filtro para imposição da pena, inegável evolução na fenomenologia do direito penal -, o adestramento social por meio da pena já se fazia presente como dado histórico. Seja enquanto instrumento de controle mediante o medo ou mesmo como punição a um comportamento contrário aos interesses dominantes, seu uso secular está umbilicalmente associado à própria formação do aparato organizado a que se denominou de Estado.

Justamente por anteceder ao direito penal, os critérios que autorizam a forma ou modelo do sistema punitivo apenas podem ser encontrados mediante uma perspectiva externa, estabelecendo um 
ponto de tensão com a amoralidade do direito classicamente apregoada. Embora não se possa desconhecer o avanço ao se defender a necessária separação entre direito e moral, não é possível, de igual modo, desconhecer a correlação entre eles existente. Nesta medida, afirma Faria Costa (2005, p. 871), a problemática dos fins da pena, inobstante permaneça vinculada ao direito penal, é estruturalmente metajurídica.

Enquanto a pena criminal possui sentido meramente ôntico, pois não representa uma dimensão naturalmente relativa ao conflito, ela deve ser compreendida como tecnologia artificialmente criada como forma de expiação. Com efeito, carece de causas que a justifiquem, ao menos teoricamente, enquanto pressuposto de validade sistêmica do instituto. A essa empreitada se prestaram as chamadas teorias da finalidade da pena, que tanto buscaram explicá-la quanto legitimála.

\section{OS DISCURSOS DE LEGITIMAÇÃO DA PENA}

O crime não possui uma existência ontológica, ou seja, uma essência rigorosamente capaz de distinguir o comportamento desviante das demais condutas humanas geradoras de conflitos sociais. Nas palavras de Hulsman (HULSMAN; CELIS, 1993, p. 64), "não há nada na natureza do fato, na sua natureza intrínseca, que permita reconhecer se se trata ou não de um crime”. Não há um denominador comum além de uma ligação completamente artificial na seleção dos casos merecedores da sanção penal. Trata-se de uma decisão humana modificável, que cria a imagem do criminoso, servindo a um poder que se exerce conforme determinado marco ideológico.

Na medida em que o exercício do poder punitivo não possui uma racionalidade imanente, surgiu a necessidade de legitimá-lo, para que a imposição de pena não fosse considerada aos olhos do povo um ato de violência arbitrária do Estado, cuja perpetuação da sua estrutura dominante depende do adestramento dos cidadãos mediante mecanismos não perceptíveis de controle. Para manter-se, o instituto da pena passa a exigir uma explicação capaz de demonstrar que, por trás da coerção penal, há um fim que autoriza a violência dos meios utilizados em defesa da ordem e do bemestar coletivo.

Impor uma sanção que desabone, mesmo que temporariamente, direitos fundamentais subjetivos, torna obrigatória a construção de um discurso que estabeleça o projeto a ser cumprido pela pena. Tal como adverte Roxin, desconsiderar a importância de se estabelecer uma finalidade ou propósito à coerção equivaleria esvaziar de sentido o direito penal como um todo: 
si el Derecho penal tiene que servir a la protección subsidiaria de bienes jurídicos y con ello al libre desarrollo del individuo, así como al mantenimiento de un orden social basado en este principio, entonces mediante este cometido sólo se determina, de momento, qué conducta puede conminar el Estado. Sin embargo, con ello no está decidido, sin más, de qué manera debería surtir efecto la pena para cumplir con la misión del Derecho penal. A esta pregunta responde la teoría sobre el fin de la pena, la cual, ciertamente, siempre tiene que referirse al fin del Derecho penal que se encuentra detrás (algo que muy a menudo no se toma suficientemente en consideración) (ROXIN, 1997, p. 81).

Inobstante as peculiaridades de cada civilização, há um consenso quanto ao fato de que as primeiras tentativas de conferir legitimidade à pena institucionalizada partiram de concepções teocráticas (FÜHRER, 2005). O poder punitivo, formado por meio da apropriação da vítima, toma para si também o argumento da divindade, passando a explicar a sanção em seus primórdios enquanto espécie de desagravo aos deuses lesados em sua vontade. Nesse sentido, destaca Hulsman (HULSMAN; CELIS, 1993, p. 68) que "há uma consonância, herdada de séculos e profundamente enraizada nas consciências, entre o sistema punitivo que conhecemos e uma certa visão religiosa do mundo”.

Durante muito tempo, a partir das civilizações mais distantes, os deuses foram utilizados na tentativa de conferir uma espécie de racionalidade para explicar não somente fenômenos naturais, mas a própria sistemática das relações humanas. Quanto a estas, afirmar que algo resultava de uma vontade sobre-humana era uma forma de despir-se do fardo de legitimar a reação a dado comportamento, que assim era aceito sem que se questionassem os fundamentos dessa racionalidade. Dessa forma, o argumento da vontade divina isentava o poder punitivo de teoricamente justificar a pena, marcada por sua natureza extremamente cruel e desproporcional (ARAÚJO, 2015).

Nesse estágio não havia critérios de racionalidade ou cientificidade. O poder punitivo - que então mantinha estreita correlação com o poder sacerdotal - estava associado à capacidade de afirmar qual seria essa vontade obscura e incompreendida de quando e de que modo a pena deveria ser imposta. Para tanto, o povo foi levado a crer e aceitar que a divindade delegava sua sagrada onipotência a um grupo restrito de pessoas no plano terreno, as quais supostamente detinham a rara capacidade de ouvir e interpretar a vontade dos deuses. Nisso residia o fundamento que legitimava a aplicação de penas aos membros do grupo, tementes à ira dos deuses.

Essa racionalidade manteve-se por séculos, até que foi parcialmente alterada pela Igreja Romana, quando o papa se valeu do estabelecimento de um poder punitivo próprio, criando a Inquisição, voltada a eliminar fisicamente os hereges. O poder inquisitorial, fruto da influência exercida pelo clero na estrutura do Estado, foi o principal responsável pela identificação do crime com o pecado e da pena como caminho para salvação. Segundo Zaffaroni (2012, p. 44), a demonologia - destacando-se os escritos de Santo Agostinho e, já no medievo, o Malleus 
maleficarum $^{3}$ - pode ser considerada a primeira teoria criminológica, na medida em que buscava explicar a etiologia do crime com vistas a legitimar o poder punitivo da inquisição eclesiástica.

Havia uma natural aceitação, fruto de um discurso moral maniqueísta, segundo o qual o crime era a materialização da vitória do mal que, por ser contrário à natureza do homem - feito à imagem e semelhança de Deus -, deveria ser expiado por meio da pena para imaterialmente garantirlhe um espaço no paraíso. Para Hulsman (HULSMAN; CELIS, 1993, p. 68), "isso explica porque [sic] a dicotomia inocente-culpado, sobre a qual se estrutura o sistema penal, é tão facilmente aceita”.

A inspiração teocrática perdurou até a laicização da sanção penal, quando o Estado - então representado pela figura do soberano -, já consolidado e forte o bastante, passou a não mais tolerar um poder punitivo paralelo que não estivesse sob o seu comando. Apenas da força soberana poderia se originar o direito de punir, que tinha no suplício seu instrumento de controle. Funcionava como se toda infração penal fosse um crimen majestatis, e qualquer criminoso um regicida em potencial.

Nesse estágio, a pena era infligida contra o corpo do ofensor, que se tornava objeto central de um degradante espetáculo alheio a qualquer hipótese de reinserção social; o ofensor, visto como inimigo público da ordem, deveria ser exemplarmente punido e, quando necessário, eliminado. O suplício, enquanto espécie de pena, era um instrumento de controle e manutenção do poder que, para triunfar diante do crime, deveria superá-lo em sua atrocidade. Não é por outro motivo que o povo era chamado a testemunhar o ato de violência, que se convertia num espetáculo em praça pública, pois o medo, utilizado estrategicamente para o funcionamento político do ato de punir, é um poderoso instrumento de controle social.

Os suplícios exerciam a função de reconstituir a soberania figurativamente lesada, reestabelecendo o poder mediante o medo, que menos objetivava estabelecer um equilíbrio que reafirmar a força ilimitada do poder punitivo. Segundo Foucault (1999, p. 43),

o que até então sustentara essa prática dos suplícios não era a economia do exemplo, no sentido em que isso será entendido na época dos ideólogos (de que a representação da pena é mais importante do que o interesse pelo crime), mas a política do medo: tornar sensível a todos, sobre o corpo do criminoso, a presença encolerizada do soberano. O suplício não restabelecia a justiça; reativava o poder. [...] Suas crueldades, sua ostentação, a violência corporal, o jogo desmesurado de forças, o cerimonial cuidadoso, enfim todo o seu aparato se engrenava no funcionamento político da penalidade.

Com a reforma penal levada a cabo no fim do século XVIII, a pena passa a ter como escopo não mais servir de instrumento à vingança do soberano, mas dar seus préstimos à sociedade, como

\footnotetext{
${ }^{3}$ Martelo das bruxas, de 1487, obra de Jacob Sprenger e Heinrich Krämer, que orientou os suplícios direcionados às bruxas e aos demais traidores da Cidade de Deus, que haviam feito pacto com os demônios.
} 
resposta justa frente a um comportamento desviado e comunitariamente ofensivo. $\mathrm{O}$ crime passa a ser visto como violação da lei e não mais de relações interpessoais, como uma espécie de lesão generalizada ao corpo social, em nome de quem a punição aos detratores estaria legitimada como instrumento, necessário à manutenção de uma convivência harmoniosa e segura:

O pensamento iluminista e a prática pós-iluminista reforçaram a tendência no sentido de definir as ofensas em termos de violação da lei ao invés de em função do dano real. [...] Se o Estado representasse a vontade e interesses populares, ficaria mais fácil justificar sua definição como vítima e entregar-lhe o monopólio das intervenções jurídicas. Mais importante, o iluminismo trouxe consigo a nova física da dor. (ZEHR, 2008, p. 113).

Em um espaço temporal muito curto toda uma transformação na administração da dor ocorreu: Do fim do século XVIII para o início do século XIX, os suplícios, espetáculos públicos da dor e da punição que se materializavam nos corpos dos condenados, foram abandonados e substituídos pelo encarceramento. A adoção da pena de prisão como pena principal traz uma aura asséptica, particularmente ao compará-la com os suplícios, que reinavam como pena principal até fins do século XVIII, conforme ilustrado no prelúdio da narrativa foucaultiana em "Vigiar e Punir" (FOUCAULT, 1999, p. 11).

Doutro lado, a liberdade conquistava definitivamente o status de bem jurídico fundamental à vida digna; não por outra razão, consagrada no emblema da Revolução Francesa. Soava muito mais racional limitar e administrar proporcional e racionalmente o tempo do condenado do que supliciá-lo em praça pública. A limitação temporal da punição confere uma aparência de racionalidade e de ciência à aplicação e administração da dor.

Ademais, a prisão é cômoda, psicologicamente falando, uma vez que coloca o condenado longe dos olhos dos “cidadãos de bem”, relegando o apenado ao esquecimento, ainda que seu martírio cumpra uma função simbólica. Some-se a isso o ideal ressocializador, tão adequado à ideia do capitalismo insurgente ao longo do século XIX, de que o homem precisa ser útil ao trabalho, e teremos os principais pilares racionais que sustentarão a adoção da pena de prisão como pena principal.

Os primeiros passos dogmáticos, contudo, em nada inovaram na realidade antes posta. Ao contrário, reintroduziram uma concepção já conhecida desde a Antiguidade: a de que a pena deve ser justa, ou seja, equivalente ao mal provocado, e isso pressupõe uma correspondência em severidade e duração com a gravidade do delito praticado. Com efeito, por trás dessa teoria retributiva - também denominada absoluta porque para ela o fim da pena é independente e desvinculado do efeito social -, havia uma correspondência ao princípio do talião (ROXIN, 1997, p. 81).

Segundo Jakobs, o modelo de pena retributiva, em que preponderavam as ideias de Kant e Hegel, teria como função imagética a tutela da justiça, concebendo na lei um imperativo a ser 
observado. Entretanto, Jakobs destaca nuances ligeiramente diferentes em Kant e em Hegel. Para aquele, a pena não poderia ser imposta senão pelo fato de alguém ter cometido um crime, pois, do contrário, o ser humano restaria colocado no direito das coisas. Para Kant, a justiça deveria ser concretizada, razão pela qual a lei penal seria um imperativo categórico cujo escopo seria a estabilidade da norma. Já na visão de Hegel, o crime seria uma espécie de negação ao direito (não somente à norma), de modo que a pena se oporia à pretensão de eficácia da violação, reestabelecendo com isso a ordem social (JAKOBS, 2009, p. 35-40).

Com efeito, a pena serviria como instrumento para restauração de uma ordem violada, como se ela pudesse simetricamente eliminar um mal já consumado pelo tempo. O objetivo era utilizar a sanção penal como recurso para manutenção do próprio poder punitivo, mediante a imposição de padrões de comportamento. Por esse motivo, afirma Ferrajoli (2014, p. 240), "tais doutrinas revelamse idôneas para justificar modelos não liberais de direito penal máximo”, cuja finalidade essencial se esgota no castigo do desvio cometido.

Dessarte, a teoria retributiva serviu tão somente como um reforço externo à vigência da norma, sem a pretensão de racionalmente legitimar a pena segundo uma finalidade social específica. A sanção seria um consectário ético, metafisicamente justificado por meio do valor moral da lei penal violada e do castigo que consequentemente deveria ser imposto. Entretanto, se a função que a racionalidade moderna relegou ao direito penal é a de proteger determinados bens jurídicos, para que cumpra tal desiderato não é possível recorrer a uma pena que expressamente prescinda de qualquer fim social.

Consequentemente, a retribuição do mal pelo mal paulatinamente se tornou um discurso vazio, passando a exigir uma nova construção teórica que transcendesse ao fato pretérito e à compensação da culpabilidade por razão dela mesma. Nesse ponto, o direito penal, enquanto “instrumento de potencialização do mal” (FARIA COSTA, 2005, p. 873), carecia de justificativa com maior densidade ético-social para o ato de penar.

Excluída a ideia de que a pena poderia apagar um evento danoso já consumado, surge uma nova racionalidade que pretende justificá-la a partir dos efeitos provocados no apenado. Seguindo uma posição diametralmente oposta à teoria retributiva, a missão da pena consistiria em dissuadir, seja o cidadão em geral, seja o autor de futuros delitos, e melhorar a pessoa do condenado; um misto de intimidação e correção. 
A prevenção especial ${ }^{4}$, levada ao extremo, fomentou um direito penal vocacionado ao autor em detrimento do fato, passando a tratar o crime como uma espécie de patologia social, assumindo a pena a fisionomia terapêutica de remédio para cura do criminoso. Desta feita, a prevenção especial propicia o aniquilamento do princípio da taxatividade, na medida em que a proporção da pena se volta à periculosidade ostentada pelo autor do fato, em detrimento da gravidade do fato em si, possibilitando a aplicação da pena por tempo indeterminado.

A terceira das teorias penais tradicionais desenvolvidas a partir do paradigma carcerário, denominada de prevenção geral, sustenta que a pena deve exercer sua influência não só sobre o autor, mas também deve passar uma mensagem psicologicamente coatora à sociedade como um todo. A preocupação com o aspecto de prevenção dos delitos segue, agora, direcionada àqueles que ainda não os tenham praticado. Parte-se do pressuposto de que a sanção é necessária porque os crimes, acaso não gerassem uma consequência para o autor, incitariam à imitação e, ademais, serviriam como reforço pessoal à reincidência.

Embora estabeleça como foco principal a comunidade, sobre quem a execução da pena deve ratificar a eficácia da norma penal, a finalidade última da aplicação da pena continua sendo a intimidação dos cidadãos. Nesse sentido, afirma Roxin (1997, p. 90),

al querer prevenir el delito mediante las normas penales, constituye fundamentalmente una teoría de la amenaza penal. Pero constituye asimismo, por la acción de su efecto, necessariamente una teoría de la imposición y de la ejecución de la pena, puesto que de esto depende la eficácia de su amenaza.

Entretanto, as teorias da prevenção foram incapazes de abandonar por completo a ideia retributiva, pois esta é indissolúvel em relação aos caracteres essenciais de proporcionalidade e justiça - fruto da reintrodução da moral no discurso jurídico da segunda metade do século XX. Na ótica de Jakobs (2009, p. 47), “existe ao menos a suspeita de que a prevenção especial apenas funciona quando flanqueada por efeitos secundários de cunho preventivo-geral”. Com base nessa constatação é que se desenvolveu a teoria unitária ou polifuncional da pena, que considera tanto a retribuição, quanto a prevenção especial e geral como fins da pena que devem ser simultaneamente perseguidos com sua imposição.

Faria Costa, por sua vez, defende um entendimento neorretributivo para justificar a existência das penas criminais. Para o autor, buscar na aplicação da pena a produção de efeitos dissuasórios, no sentido de que outros não pratiquem futuramente os mesmos atos, ou como

\footnotetext{
${ }^{4}$ Para a qual, em seu signo positivo, o fim da pena é manter o agente afastado de crimes futuros, ou seja, que o objetivo da sanção penal passa a ser eliminar a reincidência, mediante um processo de reinserção social.
} 
mecanismo de estabilização contrafática da norma violada, admitiria, em última análise, a punição de um inocente como bode expiatório e a inobservância da culpa como medida concreta. Isso o leva a concluir que apenas a retribuição obedeceria ao princípio da responsabilidade e à pretensão de igualdade material como forma de tratamento (FARIA COSTA, 2005, p. 877).

Entretanto, também a releitura da teoria da retribuição, inobstante a válida tentativa de ressignificação da função assumida pela pena criminal como mecanismo de responsabilização, limitou sua análise ao campo do dever ser. Assim como as demais teorias construídas a partir das generalizações do método indutivo, os esforços argumentativos de justificação da pena passaram ao largo de uma análise concreta dos efeitos por ela produzidos.

Como visto, houve uma consequente revisão de antigas teorias, tanto abstratas quanto fundadas em valores morais, conferindo à pena uma capilaridade quanto aos seus fundamentos. Ocorre que, ao se aumentar o rol de finalidades da pena, bem como as possibilidades de reconhecimento de pelo menos alguma das facetas apontadas como argumento da mesma, coloca-se em xeque a principal função com que o direito penal democrático deve se preocupar, qual seja, a limitação do poder punitivo do Estado (PACHECO, 2010, p. 60).

A acumulação de finalidades em abstrato, em vez de afastar as diversas dificuldades para justificar a pena, em verdade contribui para o uso autoritário de quaisquer finalidades que se queira atribuir a ela no plano discursivo. As diversas teorias, dogmaticamente construídas de modo a esconder a total ausência de finalidades humana e social da pena - hoje utilizadas como recursos de política criminal -, na prática eliminam qualquer forma de controle da atividade punitiva, que cada vez mais se volta à sumária eliminação de riscos.

Com efeito, todas essas teorias servem apenas como um recurso retórico na construção de uma justificativa para se punir, deixando de lado qualquer legitimidade real, fundamentada em dados concretos da realidade. Acaso as tentativas de justificação de fato se refletissem na prática, a consequência natural, considerando as formulações teóricas que buscaram legitimar a pena, seria uma contínua diminuição dos delitos. Se os fins pretendidos de fato pudessem ser alcançados, tal como proposto, haveria uma entronização social e uma natural minimalização da máquina penal como um todo.

Entretanto, testemunhou-se apenas a sua ampliação, demonstrando que a pena somente obedece a uma antiga lógica de poder, que se retroalimenta, do controle social levado a cabo, especialmente, pela política de encarceramento em massa. Coube à criminologia crítica, a partir de dados concretos que demonstraram a fragilidade do discurso punitivo alijado de qualquer evidência 
empírica, formular as bases para uma possível abertura para novas formas de encarar o conflito e de constituição da própria justiça criminal.

\section{A CRIMINOLOGIA CRÍTICA E O COLAPSO DAS TEORIAS DA PENA}

Os esforços empreendidos pelas teorias da pena não consideraram as implicações do sistema carcerário, fruto da paulatina transformação do objeto da ação punitiva que, desde a adoção da prisão como novo paradigma, abandona o corpo e se dirige à alma do condenado. A abolição do ritual dos suplícios no fim do século XVIII deu lugar a uma nova forma de controle, pautado no poder disciplinar sobre o corpo do condenado, relegando-nos o sistema carcerário como projeto da modernidade. Para Foucault (1999), desde sua origem a prisão tem como objetivo não só responder à infração, mas primordialmente corrigir o indivíduo de forma paralela e exterior à justiça.

Essa forma de correção, entretanto, se dá mediante uma estrutura completamente artificial. As instituições totais criam uma vivência espaço-temporal artificial ao se traçar um paralelo com a vida em sociedade - intramuros há tempo de sobra e espaço contrito, enquanto que extramuros essa equação se inverte. Isso por si só já seria um óbice ao propalado ideal ressocializador. Somem-se a isso as cerimônias degradantes, que levam à profanação do eu, e o ambiente caracterizado pela violência endógena, conforme denunciado desde a década de 60 do século passado pela ótica da reação social. A experiência do encarceramento, em vez de servir como reforço negativo à prática de novos crimes, devolve à sociedade uma massa de indivíduos completamente institucionalizados a uma ambiência criminógena. Submetido ao cativeiro, o apenado perde paulatinamente sua sociabilidade, para adequar-se à disciplina carcerária, que nada lhe ensina além da obediência forçada às rotinas intramuros que o coisificam, levando-o a uma mortificação do eu, por meio da deformação paulatina da sua personalidade (GOFFMAN, 1974).

Nas décadas de 60 e 70 do século passado, um conjunto complexo de fatores políticos criou um contexto favorável para uma crítica radical das prisões e do sistema penal como um todo; na verdade, emergiram novos matizes de percepção sobre o fenômeno criminal. Apesar de o movimento não ser uniforme em suas proposições, indo do interacionismo ao materialismo, tinha uma matriz comum a respeito daquilo que criticava e foi identificado a partir de algumas expressões que se popularizaram, tais como: “criminologia radical”, “nova criminologia”, “criminologia marxista” ou, simplesmente, “criminologia crítica”.

Um dos marcos literários dessa fase, largamente reconhecido, “A Nova Criminologia: para uma teoria social do desvio”, teve o grande mérito de organizar as principais correntes criminológicas 
até então, a fim de propor uma ruptura no pensar a criminalidade a partir do materialismo marxista (TAYLOR; WALTON; YOUNG, 1973).

Em que pese não ser o escopo deste artigo, é possível delimitar, num primeiro momento, três principais vertentes dentro da criminologia crítica: garantismo penal, realismo de esquerda e abolicionismo penal. Dentre essas tendências principais, o presente artigo ficará adstrito à corrente abolicionista, por seu papel decisivo na construção de uma crítica fecunda e capaz de deslegitimar o sistema carcerário e a lógica punitiva própria da racionalidade moderna.

Dentro do recorte abolicionista, destacaremos três dos seus principais teóricos: Louk Hulsman, Thomas Mathiesen e Nils Christie. Cada um agrega contributos essenciais à ruptura do paradigma retributivo, em tal consonância com a proposta da Justiça Restaurativa, que torna evidente a ancoragem desta na filosofia abolicionista ${ }^{5}$.

Hulsman foca que a desconstrução se inicia por meio de uma mudança da linguagem, uma mudança conceitual. Além da obra “Das penas perdidas”, bastante disseminada no Brasil, é importante destacar sua obra fundamental, Critical Criminology and the Concept of Crime, de 1986, em que propõe a desconstrução do delito, que não seria objeto, mas produto de uma política criminal que pretende justificar o exercício do poder punitivo. Sendo assim, uma vez que o delito como realidade ontológica, pedra fundamental da Justiça Retributiva, não se sustenta, tornaria insustentável a própria justiça penal, o que justificaria sua abolição.

Thomas Mathiesen, ademais de sua fecunda e radical crítica às prisões, em sua clássica obra The Politics of Abolition, de 1974, aponta três propostas principais para a abolição do sistema penal, quais sejam: a abolição das prisões; o cuidado com as propostas de alternativas à prisão que venham a reforçar a lógica punitivista, ao invés de ajudar a combatê-las e, por fim, arquitetar estratégias de curto e longo prazo, insistindo negativamente em qualquer proposta que possa vir a incrementar o sistema carcerário enquanto o fim almejado da abolição não venha a ser alcançado.

Nils Christie muito contribuiu para a construção de uma nova dinâmica de solução dos conflitos a partir da proposta de devolução dos mesmos às partes. Em seu artigo Conflicts as Property, de 1977, foi pioneiro ao centrar a crítica ao sistema penal na apropriação estatal dos conflitos, alijando as partes dos mesmos, criando uma inversão de valores que frustra qualquer possibilidade de autonomia na resolução dos próprios problemas, esvaziando, desse modo, o potencial maior dos

\footnotetext{
${ }^{5}$ Para um maior aprofundamento acerca dos contributos da vertente abolicionista a um novo repensar do conflito e das correlações com o modelo concreto de política criminal proposto pela Justiça Restaurativa, a partir dos seus destacados três principais teóricos - Hulsman, Christie e Mathiesen -, ver Daniel Achutti (2014, p. 89-124).
} 
conflitos que reside justamente, em sua visão (consonante com a visão restaurativa), em oportunizar aos cidadãos a administração dos seus próprios conflitos.

O pensamento abolicionista, desenvolvido no seio da criminologia crítica, tinha como um dos temas centrais a abolição do cárcere como meta, ainda que de longo prazo, assentado no argumento da irracionalidade da prisão, que passou a ser denunciada, particularmente por Mathiesen (1997, p. 263), como um sofrimento estéril e desprovido de sentido.

A análise do sistema penal, a partir do ambiente carcerário, demonstrou empiricamente que a justiça penal é extremamente seletiva, recrutando seus membros principalmente das zonas periféricas, refletindo uma realidade social extremamente desigual que busca excluir os pobres do seu convívio. A questão, afirma Mathiesen (1997, p. 273), “não é a reabilitação dos transgressores e nem prevenir outros de cometerem atos similares, mas simplesmente retirar os transgressores do circuito social”; esse é o real propósito que a racionalidade penal moderna busca acobertar.

“A aplicação seletiva das sanções penais estigmatizantes, e especialmente o cárcere, é um momento superestrutural essencial para a manutenção da escala vertical da sociedade” (BARATTA, 2014, p. 166), servindo como reforço à manutenção do poder nas mãos daqueles que já o detêm.

Seguindo nessa perspectiva de controle dos corpos, o viés marxiano da criminologia crítica possibilita correlacionar o investimento que se faz na despersonalização do sujeito, segundo relações complexas e recíprocas, à sua utilização econômica. "É, numa boa proporção, como força de produção que o corpo é investido por relações de poder e de dominação; mas em compensação sua constituição como força de trabalho só é possível se ele está preso num sistema de sujeição” (FOUCAULT, 1999, p. 25-26). Todavia, mesmo no cumprimento do antigo desiderato capitalista de transformar os apenados em uma massa que pudesse servir ulteriormente como mão de obra ao capital - o cárcere também falhou. Se de fato era este um dos objetivos velados da estrutura penitenciária, foi ele abandonado na medida em que a superlotação transformou cadeias e penitenciárias em verdadeiros depósitos abarrotados de seres humanos, convertendo-se em “fábricas de imobilidade” (BAUMAN, 1999, p. 113).

Conclui-se que a análise realista das funções exercidas por esse sistema, fracassado para os fins de controle da criminalidade e reinserção social, "não pode deixar de levar a uma consequência radical na individualização do objetivo final da estratégia alternativa: este objetivo é a abolição da instituição carcerária” (BARATTA, 2014, p. 203), que é a própria antítese de uma sociedade livre, consciente e civilizada. 
O movimento iluminista, com sua pretensa racionalidade, acabou por instituir um sistema punitivo irracional, entretanto “a irracionalidade verdadeira da prisão é um dos segredos mais bem guardados em nossa sociedade” (MATHIESEN, 1997, p. 277).

A prisão é "um gigante sobre um solo de barro", conforme alegoria apresentada por Mathiesen, ao denunciar a total irracionalidade da prisão em termos de seus próprios objetivos estabelecidos e jamais alcançados. Ratificando o que foi até aqui apresentado, Mathiesen cita os cinco objetivos principais não alcançados da pena de prisão, quais sejam: reabilitação; intimidação do transgressor; prevenção geral, ou seja, efeitos dissuasórios na sociedade em geral; interdição dos transgressores, retirando-os do convívio social e proporcionalidade, que tampouco pode ser satisfeita por meio do encarceramento, uma vez que se trata de balancear duas entidades incomensuráveis, que são a transgressão criminal de um lado e o tempo do transgressor de outro.

Assim, conclui Mathiesen pela total irracionalidade da prisão, que, se não fosse tão bem guardada por seus três principais defensores (os administradores do sistema criminal, os intelectuais e pesquisadores e a mídia), estaria colocada numa situação tão fragilizada que um clima de desmantelamento das prisões deveria, necessariamente, começar já (MATHIESEN, 1997, p. 270282).

Como destacado por Ferrajoli (2014, p. 235), o abolicionismo "teve o mérito de favorecer a autonomia da criminologia crítica”. Inobstante o autor defenda a pena enquanto técnica institucional para minimização de excessos punitivos - inclusive de sistemas não jurídicos de controle social -, reconhece ele o fato de que as críticas feitas pelo abolicionismo teórico de certo modo deslegitimaram o direito penal a partir de um ponto de vista externo ao sistema. Se as funções da pena são falsas, cai completamente no vazio a intenção de legitimar sua aplicação, de modo que a justiça acaba se convertendo em simples etiqueta despida de função social.

Contudo, essa sucessão de argumentos e teorias, em que pese inidôneas, produziu um resultado que não pode ser desconsiderado: a falsa crença de que a reação punitiva é o único instrumento capaz de responder à criminalidade. O imaginário popular acostumou-se a ver na prisão o instrumento de vingança legítima do Estado e da recuperação do apenado, crença coletiva esta que dificulta a superação de um antigo modelo, sobretudo quando o discurso da violência é utilizado no contexto de uma hipercultura midiática. 


\section{A JUSTIÇA RESTAURATIVA COMO NOVO PARADIGMA}

É possível afirmar que os três principais autores abolicionistas que tomamos por base, após colocarem em xeque a racionalidade penal moderna, chegaram a delinear um possível caminho de ruptura que nos levasse a um novo paradigma de administração da justiça?

Essa questão posta nos leva a uma conexão central entre as críticas abolicionistas e as propostas da Justiça Restaurativa: seja a partir de uma ruptura por meio da linguagem e da reconstrução do conceito de crime por Hulsman, seja mediante a deslegitimação da pena de prisão e das propostas político-criminais de curto e longo prazo de Mathiesen, seja, por fim e especialmente, a partir da leitura de Christie, em sua análise fecunda acerca da administração centralizada da justiça penal pelo Estado, que o levou a propor que esta deveria ser substituída por formas descentralizadas de resoluções de conflitos, em que os conflitos deveriam "se tornar úteis para aqueles originalmente envolvidos no conflito" (CHRISTIE, 1977, p. 1) ${ }^{6}$.

A partir deste momento, dediquemo-nos a analisar a convergência das críticas elaboradas por Christie, Hulsman e Mathiesen com as proposições da Justiça Restaurativa, acerca da construção de um novo paradigma sobre o conflito.

Para Christie, uma alternativa funcional ao encarceramento estaria para surgir ou estruturarse em muitas sociedades industrializadas. Uma dessas alternativas factíveis seriam os comitês de mediação ou conselhos para soluções alternativas a conflitos, como às vezes são chamados. Segundo o autor, "[alternativas fora dessa racionalidade penal] aparecem de diferentes formas, mas na maioria são construídas baseadas na mesma ideia: as partes em conflito devem ter a chance de se reunir, pessoas de fora devem ajudá-las” (CHRISTIE, 1997, p. 252). Muito antes de a proposta de justiça dialógica, nos moldes da Justiça Restaurativa, ganhar corpo, Christie, em sua palestra conferida na inauguração do Centro de Criminologia da Universidade de Sheffield, na Inglaterra, em 19767, já reivindicava um modelo de administração de conflitos que fosse orientado à vítima, que focasse suas necessidades, a partir de um modelo de tribunal de vizinhança - neighborhood court -, conforme denominação por ele utilizada naquele momento emblemático (CHRISTIE, 1977, p. 10).

Hulsman destaca que "a maioria das alternativas para a justiça penal é de natureza predominantemente não-legal” (HULSMAN; CELIS, 1993, p. 164). As respostas penais tradicionais para eventos criminalizáveis inibem o desenvolvimento social e pessoal dos envolvidos, de modo que

\footnotetext{
${ }^{6}$ Tradução livre. Segue o original: "Conflicts ought to be used, not only left in erosion. And they ought to be used, and become useful, for those originally involved in the conflict."

${ }^{7}$ Essa palestra veio a ser publicada em 1977, com o título Conflict as Property, no The British Journal of Criminology, conforme já mencionado.
} 
é necessário reativar o diálogo para encontrar uma linguagem própria e diversa daquela orientada pela lógica penal. Como exemplo, cita o autor a fórmula dos community boards, em que conciliadores formam comissões ad hoc, compostas por membros escolhidos de acordo com o caso, servindo como facilitadores do diálogo para construção de uma solução formada pelas próprias partes (HULSMAN; CELIS, 1993, p. 134).

Mathiesen, por sua vez, afirma que as vítimas não recebem nenhum apoio do sistema de justiça penal tradicional e propõe "guinar o sistema em 180 graus: ao invés de aumentar a punição do transgressor de acordo com a gravidade da transgressão, o que é básico no sistema atual, eu proporia o aumento de apoio à vítima de acordo com a gravidade da transgressão” (MATHIESEN, 1997, p. 276). Ele ainda propõe um olhar inclusivo também ao transgressor, na forma de uma série de medidas que visem a um combate à pobreza, tais como: moradias decentes, programas de trabalho, de educação e de tratamento que não sejam baseados na força e, o mais importante, em seu entender, uma mudança radical na política sobre drogas. A partir de uma política de descriminalização das drogas, que estaria inserida naquele propósito mais largo, também defendido por ele, de abertura paulatina do sistema carcerário, haveria mudanças em duas frentes, pois não só haveria uma considerável diminuição no encarceramento, mas também se atingiria o centro da criminalidade organizada que se engendra ao redor da política de drogas. Mathiesen (1997, p. 277) conclui com uma provocação acerca de quem pagaria por isso e nos dá a seguinte resposta: “as prisões. O desmantelamento das prisões daria somas vultosas de dinheiro, bilhões e bilhões de dólares americanos, que poderiam ser gastos, generosamente, com as vítimas e os transgressores.”

Diante disso, a proposta da Justiça Restaurativa é uma espécie de concretização daquilo que Molina compreende como criminologia moderna, que "parte da análise da realidade para, de novo, a ela retornar, para transformá-la e melhorá-la” (MOLINA, 2010, p. 582). Ela adota as premissas do abolicionismo para, consciente das falhas do sistema penal clássico, propor uma nova forma de encarar o evento criminalizável e construir uma resposta concreta e dialógica para cada caso, que seja capaz de produzir resultados sustentáveis, numa perspectiva de uma política criminal concreta.

Na visão de Lederach (2012, p. 37), “os conflitos acontecem. Sua presença nos relacionamentos humanos é normal e perene”, a grande questão é que eles devem ser encarados a partir de novas perspectivas. Com base nisso, propõe o autor que os conflitos são oportunidades de criar processos contínuos de mudança que reduzam a violência nas estruturas sociais a partir da retomada do diálogo e do consequente empoderamento das partes envolvidas no problema.

Para tanto, há a necessidade de se abandonar antigos dogmas, como a neutralização da vítima e a visão estereotipada do delinquente. Quanto a este, impõe-se admitir sua normalidade como 
postulado, reconhecendo que a transgressão à norma penal não desqualifica sua humanidade nem lhe contamina com qualquer tipo de patologia individual. Já em relação à vítima - originalmente apropriada em seu protagonismo pelo poder punitivo -, que não só sofre imediatamente os efeitos derivados do delito, mas também é secundariamente vitimizada pelo processo penal, é importante lhe conferir papel dinâmico e ativo na resolução do conflito (MOLINA, 2010, p. 581-601).

É evidente o contraponto estabelecido entre a Justiça Restaurativa e o modelo clássico de Justiça Retributiva, na medida em que aquela propõe a retomada do protagonismo pelas partes envolvidas no evento danoso, dando-lhes voz e poder no processo de construção de um acordo que recomponha o tecido social lesionado. Há, com efeito, uma ruptura com a racionalidade hierárquica do poder punitivo, horizontalizando a relação como meio para que a vítima seja acolhida e o ofensor adequadamente responsabilizado e conscientizado acerca dos danos provocados pelo seu comportamento.

Segundo Zehr, as duas modalidades de justiça partem de um objetivo primário comum, que é o de acertar as contas. A diferença estaria nas propostas para se equilibrar a balança:

\begin{abstract}
A Justiça Retributiva postula que a dor é o elemento capaz de acertar as contas, mas na prática ela vem se mostrando contraproducente, tanto para vítima quanto para o ofensor. Por outro lado, a teoria da Justiça Restaurativa sustenta que o único elemento apto para realmente acertar as contas é a conjugação do reconhecimento dos danos sofridos pela vítima e suas necessidades ao esforço ativo para estimular o ofensor a assumir a responsabilidade, corrigir os males e tratar as causas daquele comportamento (ZEHR, 2012, p. 72).
\end{abstract}

O modelo de Justiça Restaurativa surge, então, como uma alternativa ao modelo retributivo, como uma nova forma de enxergar o crime e a justiça. A Justiça Restaurativa, apesar de ter ganhado força na década de 1990 como uma alternativa à Justiça Retributiva, alvo de tantas críticas, tem suas origens em um passado distante, quando era utilizada pelas sociedades comunais ou pré-estatais, quando a própria comunidade buscava uma solução para os conflitos lá surgidos que não implicava necessariamente a aplicação de uma punição, mas, sobretudo, numa solução negociada entre vítima, agressor e comunidade.

O crime, para a Justiça Restaurativa, deixa de ser considerado como uma violação contra o Estado e a sociedade e representa uma violação dos relacionamentos, centrando o foco nas pessoas envolvidas e na comunidade, diferentemente do modelo retributivo de justiça criminal.

A lente restaurativa se concentra basicamente na comunidade, nas dimensões sociais. A Justiça Retributiva define o Estado como vítima, define o comportamento danoso como violação da lei penal e considera irrelevante o relacionamento entre vítima e ofensor. Os crimes, portanto, estão em outra categoria, separados dos outros tipos de dano. A lente restaurativa identifica as pessoas 
como vítimas e reconhece a centralidade das dimensões interpessoais. As ofensas são definidas como danos pessoais e como relacionamentos interpessoais. O crime é uma violação de pessoas e relacionamentos (ZEHR, 2008, p. 174).

Mas não é só o crime que é enxergado com um novo olhar; a ideia de justiça no modelo restaurativo também é distinta, deixa ter como objetivo a retribuição e passa a centrar o foco na reparação e cura para as vítimas pelos danos causados em razão do conflito gerado pela prática delitiva, ou seja, as vítimas assumem uma posição de protagonistas do processo, diferentemente do modelo retributivo de justiça criminal. Ademais, é importante ressaltar que "as vítimas muitas vezes são favoráveis a penas reparativas que não envolvem o encarceramento - na verdade, muito mais vezes do que se faz em público. Além disso, elas frequentemente listam a reabilitação do ofensor como algo importante” (ZEHR, 2008, p. 182).

A cura, por isso mesmo, também deve se estender ao agressor, devendo ele ser estimulado a mudar, sem que isso implique deixar de ser responsabilizado pelos seus atos. Por fim, também a comunidade diretamente envolvida no conflito gerado pelo crime precisa de cura, pois este também repercute no meio social. A reparação e a resolução do conflito não são os únicos objetivos que devem ser buscados pela Justiça Restaurativa, deve-se sanar o relacionamento entre vítima e ofensor. Para o atingimento de tais objetivos é de fundamental importância que o processo decisório deixe de ser um ato exclusivo de uma autoridade e que seja compartilhado com as pessoas diretamente envolvidas no conflito (vítima, agressor e comunidade). Tal decisão, construída dessa forma, além de ter mais legitimidade, terá mais força para promover a cura dos danos advindos da infração à vítima e o processo de mudança do agressor (PINTO, 2005, p. 25).

Por não se tratar de um conceito fechado - ainda está em construção -, a Justiça Restaurativa se revela por meio de várias práticas que vão se espalhando por todo o mundo, inclusive no Brasil, tais como a conferência de família, a mediação entre vítima e ofensor e o círculo restaurativo. Talvez a mediação seja a prática restaurativa mais difundida no mundo e com mais tempo de aplicação.

Os teóricos da Justiça Restaurativa são bastante enfáticos em dizer que, mais importante que a metodologia que se utilize (mediação vítima-ofensor, comunicação não violenta, conferências de família, círculo de construção de paz, etc.), é o respeito aos princípios e valores da Justiça Restaurativa. Eles funcionam como termômetro do grau de restauração que uma prática pode oferecer.

Seja qual for a prática restaurativa utilizada, deve-se observar, de acordo com Pallamolla (2009, p. 62), valores considerados obrigatórios por Braithwaite, um dos maiores estudiosos acerca do tema: a não dominação, devendo o mediador atuar no sentido de impedir que uma parte se 
sobreponha à outra; o empoderamento, que é fazer com que as partes, em especial a vítima, tenham consciência de que são a peça-chave no processo decisório; obediência aos limites das sanções acaso impostas, para que não se tornem aviltantes ou degradantes; a escuta respeitosa de cada uma das partes envolvidas no conflito; tratamento isonômico e, por fim, talvez o mais importante - a voluntariedade, devendo ser dado tanto à vítima quanto ao agressor o direito de optar por participar de uma prática restaurativa ou de um processo nos moldes tradicionais de natureza retributiva.

Neste sentido, vale destacar o artigo $3^{\circ}$ da Resolução 2002/12 do Conselho Econômico e Social da ONU, que dispõe sobre os princípios básicos para a aplicação de programas de Justiça Restaurativa:

Processo restaurativo significa qualquer processo em que a vítima e o infrator e, quando apropriado, quaisquer outras pessoas ou membros da comunidade afetados por um crime, participem conjuntamente e de forma ativa na resolução das questões que o conflito origina, usualmente com a ajuda de um facilitador. Entre os processos restaurativos incluem-se a mediação, a conciliação, a celebração de conversas (conferencing) e reuniões para decidir a sanção (sentencing circles).

Em âmbito nacional, a Resolução 225 do Conselho Nacional de Justiça, de 31 de maio de 2016, que dispõe sobre a Política Nacional de Justiça Restaurativa no âmbito do Poder Judiciário, em seu artigo $1^{\circ}$, parágrafo $1^{\circ}, \mathrm{V}$, afirma que o enfoque restaurativo é a

abordagem diferenciada das situações descritas no caput deste artigo, ou dos contextos a elas relacionados, compreendendo os seguintes elementos: a) participação dos envolvidos, das famílias e das comunidades; b) atenção às necessidades legítimas da vítima e do ofensor; c) reparação dos danos sofridos; d) compartilhamento de responsabilidades e obrigações entre ofensor, vítima, famílias e comunidade para superação das causas e consequências do ocorrido.

A Justiça Restaurativa propõe um repensar do conflito, chamando as partes ao diálogo para que dele surja uma solução que considere as diversas implicações sociais do evento danoso. O modelo, portanto, não tem na rigidez uma característica, admitindo um incontável número de possibilidades e formatações, que podem inclusive dialogar com o sistema penal, atuar paralelamente a ele ou mesmo após a resposta penal. Nesta última perspectiva, as metodologias restaurativas podem servir de ponte para propiciar um melhor acolhimento do apenado, egresso do sistema penal, em sua comunidade, reconstruindo os laços de pertencimento comunitário, imprescindíveis a qualquer iniciativa de reinserção social. Ademais, não se deve perder de vista a necessidade imperiosa de acolher a vítima, classicamente alijada de todo o processo de atribuição de responsabilidade.

A proposta de devolver o conflito às partes e à comunidade é central desde as críticas abolicionistas e é retomada pela Justiça Restaurativa numa perspectiva de construção de um modelo concreto de política criminal que, focando as necessidades da vítima, crie possibilidades de reparação 
dos danos e ajustamento horizontal do conflito com vistas no porvir. Eis, portanto, o novo paradigma de exercício não só do poder de punir, mas, quiçá, um novo paradigma de enxergar e lidar concretamente com o conflito, rompendo com a racionalidade penal moderna, que nos captura na vivência do conflito como punição e castigo, e propondo um olhar sobre o conflito como parte da experiência de estar no mundo, catalisador não só de dor, mas também de possibilidades positivas e de transformação, tanto individual quanto comunitária, para o futuro.

\section{CONCLUSÃO}

Por séculos a fio, desde os chefes de agrupamentos humanos, passando por reis e soberanos, até a consolidação da estrutura hierárquica do Estado, a tentativa de compreender a punição tornouse a constante de uma longa história ainda distante do seu clímax. Esse lugar comum, entretanto, conquanto tenha criado uma temerária aproximação da sociedade com o instituto da pena, não logrou legitimá-la socialmente. A falência do sistema carcerário não é mais um discurso, mas uma constatação.

Não há como negar que a racionalidade da pena de prisão chegou ao seu limite de saturação e que o encarceramento a nada se presta além do afastamento provisório do condenado, que invariavelmente retornará ao convívio em uma sociedade que lhe desprezou e tentou a todo custo esquecê-lo dentro de uma estrutura onde as políticas públicas, afora as de dominação, não conseguem penetrar. Novas roupagens teóricas são insusceptíveis de alterar esse conteúdo putrefato do cárcere, que nada mais produz além de uma massa de sujeitos estereotipados, vítimas de uma estrutura que tanto não previne o acontecimento de novos crimes, quanto não garante um retorno sadio e harmônico do apenado que, mesmo quando solto, permanece completamente marginalizado, seja pela autoimagem deformada, seja pela imagem estigmatizada que projeta no corpo social.

Porquanto saturado, o atual modelo de sanção penal deve ser criticamente analisado e, consequentemente, ressignificado. Novas perspectivas devem ser buscadas para responder às mesmas questões que ainda não foram superadas. Há, pois, que se buscar um novo paradigma, encarando o crime tal como ele é em sua essência: um conflito. Embora difícil, o paradigma punitivo precisa ser superado para que se conceba que responsabilização prescinde de imposição de pena e que a judicialização - ou seja, a entrega do conflito ao sistema penal retributivo -, considerado os seus instrumentos de coerção, é ineficaz na construção de uma cultura de paz sustentável.

Dentre as saídas possíveis, destaca-se o modelo consensual da Justiça Restaurativa, ancorado nas propostas de ruptura da criminologia crítica e, mais particularmente, conforme foi observado, nas 
propostas abolicionistas, indo além de uma utopia e se constituindo como uma proposta de política criminal concreta. O modelo restaurativo é inteligentemente fluido a ponto de admitir uma convivência com o sistema penal tradicional; entretanto, sem perder de vista a imperiosa necessidade de repensar toda a abordagem acerca do crime. A proposta é servir como instrumento de humanização do sistema penal, ao devolver o conflito às partes e à comunidade, sem, contudo, abrir mão das salvaguardas e garantias constitucionais, numa proposta de uma nova racionalidade que transcenda a vivência do crime como castigo e punição.

Mas como tudo que é novo, suas propostas ainda causam certa estranheza e distanciamento, sobretudo àqueles que não as conhecem. É necessário, pois, abandonar os preconceitos e considerar novas possibilidades, novos caminhos que conduzam a uma resposta que satisfaça aos anseios sociais e que efetivamente possa extrair do conflito uma perspectiva de transformação positiva. Em meio ao caos do sistema carcerário, a Justiça Restaurativa é uma resposta factível a ser mais bem estruturada, despontando como um feixe de luz na escuridão, que possibilite uma paulatina ruptura de nossa vetusta racionalidade penal.

\section{REFERÊNCIAS}

ACHUTTI, Daniel. Justiça Restaurativa e Abolicionismo Penal: contribuições para um novo modelo de administração de conflitos no Brasil. São Paulo: Saraiva, 2014.

ARAÚJO, Fabio Roque da Silva. Construção histórica da contenção do poder punitivo: dos primórdios ao direito penal liberal. Revista da Faculdade Mineira de Direito, v. 18, n. 35, 2015. Disponível em: <https://goo.gl/Khvskh>. Acesso em: 7 jul. 2016.

BARATTA, Alessandro. Criminologia crítica e crítica ao direito penal: introdução à sociologia do direito penal. Tradução Juarez Cirino dos Santos. 6. ed. Rio de Janeiro: Instituto Carioca de Criminologia, 2014.

BAUMAN, Zygmunt. Globalização - as consequências humanas. Tradução Marcus Penchel. RJ: Jorge Zahar Editor, 1999.

CHRISTIE, Nils. Civilidade e Estado. Tradução Beatriz Scigliano Careiro. In: PASSETI, Edson; SILVA, Roberto Batista Dias da (Org.). Conversações abolicionistas: uma crítica do sistema penal e da sociedade punitiva. São Paulo: IBCCrim, 1997, p. 241-257.

CHRISTIE, Nils. Conflicts as Property. In: The British Journal of Criminology, vol. 17, n. 1, 1977.

FARIA COSTA, José de. Uma ponte entre o direito penal e a filosofia penal: lugar de encontro sobre o sentido da pena. In: FARIA COSTA, José de. Linhas de direito penal e de filosofia: alguns cruzamentos reflexivos. Coimbra: Coimbra Editora, 2005, p. 867-881. 
FERRAJOLI, Luigi. Direito e razão: teoria do garantismo penal. Tradução Ana Paula Z. Sica, Fauzi H. Choukr, Juarez Tavares e Luís F. Gomes. 4. ed. São Paulo: Revista dos Tribunais, 2014.

FOUCAULT, Michel. Vigiar e punir: nascimento da prisão. Tradução Raquel Ramalhete. 20. ed. Petrópolis: Vozes, 1999.

FÜHRER, Maximiliano Roberto Ernesto. História do direito penal: crime natural e crime de plástico. São Paulo: Malheiros, 2005.

GARCIA ALBERTO, Ramón. La relación entre ilícito penal e ilícito administrativo: texto y contexto de la teoria sobre la distinción de ilícitos. In: PRATS, Fermín Morales; OLIVARES, Gonzalo Quintero (Org.). El nuevo derecho penal español - estúdios penales en memória del professor José Manuel Valle Muñiz. Pamplona: Aranzadi, 2001, p. 295-400.

GOFFMAN, Ervin. Manicômios, prisões e conventos. Tradução Dante Moreira Leite. São Paulo: Ed. Perspectiva, 1974.

HULSMAN, Louk. Critical Criminology and the Concept of Crime. In: Contemporary Crises, vol. 10, n. 1. Amsterdam: Elsevier, 1986.

HULSMAN, Louk; CELIS, Jacqueline Bernat de. Penas perdidas: o sistema penal em questão. Tradução Maria Lúcia Karam. Niterói: Luam, 1993.

JAKOBS, Günther. Tratado de direito penal: teoria do injusto e culpabilidade. Tradução Geraldo de Carvalho e Gercélia Batista de Oliveira Mendes. Belo Horizonte: Del Rey, 2009.

KARAM, Maria Lúcia. Utopia transformadora e abolição do sistema penal. In: PASSETI, Edson; SILVA, Roberto Batista Dias da (Org.). Conversações abolicionistas: uma crítica do sistema penal e da sociedade punitiva. São Paulo: IBCCrim, 1997, p. 67-84.

LAPLANTINE, François. Aprender antropologia. Tradução Marie-Agnès Chauvel. São Paulo: Brasiliense, 2003.

LEDERACH. John Paul. Transformação de conflitos. Teoria e Prática. Tradução Tônia Van Acker. São Paulo: Palas Athena, 2012.

LISZT, Franz von. Tratado de direito penal alemão. Tradução José Hygino Duarte Pereira. Brasília: Senado Federal, Superior Tribunal de Justiça, 2006.

MATHIESEN, Thomas. A caminho do século XXI: abolição, um sonho impossível? In: PASSETI, Edson; SILVA, Roberto Batista Dias da (Org.). Conversações abolicionistas: uma crítica do sistema penal e da sociedade punitiva. São Paulo: IBCCrim, 1997, p. 263-87.

MOLINA, Antonio García-Pablos de. Momento atual de reflexão criminológica. In: FRANCO, Alberto Silva; NUCCI, Guilherme de Souza. Doutrinas essenciais - direito penal. São Paulo: Revista dos Tribunais, 2010, v. VI, p. 581-602.

NIETO, Alejandro. Derecho administrativo sancionador. Madrid: Tecnos, 2012. 
PACHECO, Alcides Marques Porto. Há um retorno do pensamento retribucionista? Sobre a (des)conformidade entre teoria da pena, política punitiva e legitimação. In: FRANCO, Alberto Silva; NUCCI, Guilherme de Souza. Doutrinas essenciais - direito penal. São Paulo: Revista dos Tribunais, 2010, v. IV, p. 27-68.

PALLAMOLLA, Raffaella de Porciuncula. Justiça Restaurativa: da teoria à prática. (monografias/IBCCRIM, n. 52). São Paulo: IBCCRIM, 2009.

PINTO, Renato Sócrates Gomes. Justiça restaurativa é possível no Brasil? Disponível em: <https://goo.gl/k8ro6Q>. Acesso em: 20 set. 2017.

ROXIN, Claus. Derecho Penal. Parte General. Tomo I. Fundamentos: la estructura de la Teoría del Delito. Madrid: Editorial Civitas, 1997.

SCHEERER, Sebastian ¿La pena criminal como herencia cultural de la humanidade? In: FRANCO, Alberto Silva; NUCCI, Guilherme de Souza. Doutrinas essenciais - direito penal. São Paulo: Revista dos Tribunais, 2010, v. IV, p. 965-978.

STRATENWERTH, Günter ¿Qué aporta la teoria de los fines de la pena? In: FRANCO, Alberto Silva; NUCCI, Guilherme de Souza. Doutrinas essenciais - direito penal. São Paulo: Revista dos Tribunais, 2010, v. IV, p. 451-470.

TAYLOR, Ian; WALTON, Paul; YOUNG, Jock. The new criminology: for a social theory of deviance. Londres: Routledge and Kegan Paul, 1973.

ZAFFARONI, Eugenio Raúl. A palavra dos mortos: conferências de criminologia cautelar. São Paulo: Saraiva, 2012.

ZEHR, Howard. Justiça Restaurativa. Teoria e Prática. Tradução Tônia Van Acker. São Paulo: Palas Athena, 2012.

ZEHR, Howard. Trocando as lentes: um novo foco sobre o crime e a justiça. Tradução Tônia Van Acker. São Paulo: Palas Athena, 2008.

Daniela Carvalho Almeida da Costa Doutora (2005) e Mestre (2001) em Direito pela Universidade de São Paulo. Professora do quadro permanente (Graduação e Pós-Graduação - Mestrado - em Direito) da Universidade Federal de Sergipe (UFS). Professora (Graduação) na Faculdade de Administração e Negócios de Sergipe (FANESE). Professora na Escola da Magistratura de Sergipe (ESMESE).E-mail: dancacosta@hotmail.com

Elisio Augusto de Souza Machado Júnior Mestrando em Direito pela Universidade Federal de Sergipe (UFS). Pesquisador com bolsa de fomento concedida pela Fapitec/SE.E-mail: elisio_machado@hotmail.com 